\title{
Derfor bør du spise antioksidantrike matvarer
}

\author{
Et kosthold rikt på bær, frukt og grønnsaker beskytter mot kroniske \\ sykdommer. En av årsakene kan være at de øker uttrykket av gener \\ assosiert med forsvars- og reparasjonsprosesser i kroppen.
}

Man har lenge visst at frukt og grønt beskytter mot kroniske sykdommer som hjerte- og karsykdom, kreft og Alzheimers sykdom, men man vet ikke hvordan de virker, om noen grønnsaker beskytter mer enn andre og hvordan de påvirker molekylære mekanismer i kroppen. Siv Kjølsrud Bøhn har i sin avhandling undersøkt noe av dette nærmere.

- I to kliniske studier har jeg oppdaget at inntak av antioksidantrike matvarer øker mengden av genprodukter som er assosiert med forsvars- og reparasjonsprosesser i blodceller. Dette kan bety at fytokjemikalier (plantekjemikalier) stimulerer kroppens eget forsvar, hvilket igjen vil kunne beskytte mot utvikling av en rekke sykdommer. Vi vet ikke om denne effekten skyldes en antioksidanteffekt eller andre egenskaper hos fytokjemikaliene, sier Bøhn.

I en studie av eldre menn med subjektiv hukommelsessvikt fant hun at nivået av inflammasjonsrelevante bio- og vevsskade- markører ble lavere hos de mennene som drakk blåbær-/druejuice i ni uker, sammenliknet med dem som drakk placebojuice. Hun har også undersøkt hvordan antioksidanter virker på kroppens respons på strålebehandling for pasienter med kreft i hode, nakke og halsregion.

- Pasienter med høy antioksidantstatus og lavt oksidativt stress i blodet responderte bedre på behandling og hadde større sannsynlighet for å overleve enn de som hadde lav antioksidantstatus og høyt oksidativt stress. Resultatene tyder på at det kan være mange fordeler med å spise mer frukt og grønt. I tillegg til å øke muligheten for å forebygge en rekke sykdommer kan man kanskje også øke sjansen for å overleve kreftsykdommer, sier Bøhn.

\section{Eline Feiring}

eline.feiring@legeforeningen.no

Tidsskriftet

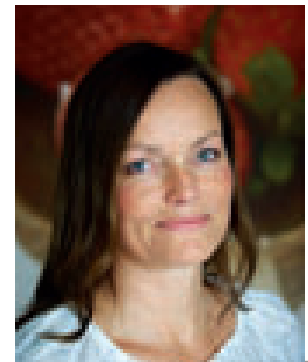

Siv Kjølsrud Bøhn. Foto Jeff Atkinson

Disputas

Siv Kjølsrud Bøhn disputerte for ph.d.-graden ved Universitetet i Oslo 23.9. 2011, med avhandlingen Antioxidant-rich foods induce genes associated with stress defence. Implications for cancer and other oxidative stress related conditions.

\section{Hivsmitte fra mor til barn}

\section{Helseprogram øker mødrenes kunnskap om mor-til-barn-smitte. Informasjon om preventive tiltak og mating av spedbarn må rettes både mot den gravide, hennes partner og svigermor.}

Helseprogrammet for forhindring av mortil-barn-smitte (PMTCT) av hiv i Kilimanjaro-området i Tanzania ble innført som pilotprosjekt i år 2000. Eli Fjeld Falnes har studert mødres kunnskap om og bruk av helseprogrammet åtte år senere. Studien viser at mødrenes kunnskap om mor-til-barn-smitte har økt. Men det er behov for tiltak for å øke mennenes deltakelse i programmet.

- Innføring av hivtest som en rutinemessig del av svangerskapsomsorgen har redusert stigma assosiert med dette, og alle gravide som fikk tilbud, tok hivtesten. Partneren støttet opp, men svært få fulgte konene sine til klinikken for å ta hivtesten. Kvinnene har ingen myndighet til å forlange testing av mannen, og svangerskapsklinikken, som tilbyr testing, anses som et sted for kvinner.

- Menn var også negative til anbefalinger om å bruke kondom gjennom svangerskapet og ammeperioden, sier Falnes.

Sykepleierne var kunnskapsrike og moti- verte, men hadde ikke nok tid til å gi råd til mødrene. Måten en hivsmittet mor ble anbefalt å mate barnet på - utelukkende erstatningsføde eller utelukkende amming - kom i konflikt med lokal kunnskap og tradisjon, og gjorde mødrene forvirret. Svigermoren, som så seg selv som ansvarlig for helsespørsmål i familien, kunne insistere på tradisjonell mating som ikke samsvarte med rådene hivsmittede mødre fikk. Dette kan øke risiko for hivsmitte til barnet. Menn aksepterte ofte ikke at kvinnen matet barnet på annen måte enn den tradisjonelle.

- Det er behov for å øke rådgivningskapasiteten, og rådene som gis, må være klare. Det er viktig at informasjonen om mating av barnet også når svigermor, og at faren inkluderes som aktiv partner, sier Falnes.

\section{Anne Forus}

anneforus@hotmail.com

Tidsskriftet

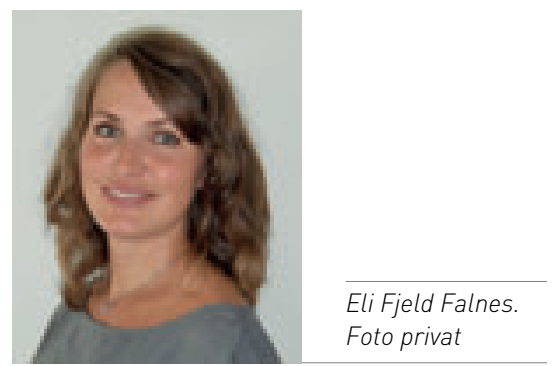

Disputas

Eli Fjeld Falnes disputerte for ph.d.-graden ved Universitetet i Bergen 5.9. 2011. Tittelen på avhandlingen er The mother, her confidants and the prevention of mother-to-child transmission of HIV (PMTCT) services in the Kilimanjaro region, Tanzania. 